\title{
MANFAAT TEKNIK REBOZO TERHADAP KEMAJUAN PERSALINAN
}

\author{
Durrotun Munafiah ${ }^{1}$, Lestari Puji Astuti ${ }^{2}$ Mike Mitrasari Parada ${ }^{3}$, \\ Maria Rosa Mistica Demu ${ }^{4}$
}

1,2,3,4 Prodi Kebidanan, STIKes Karya Husada Semarang, Indonesia

\begin{abstract}
The birth process is to help and encourage safe and healthy births for mothers and babies, so that the roles and responsibilities of health workers are needed to anticipate and overcome the complications that occur in labor. Prolonged labor is one of the factors that influence maternal mortality. The result of the Survey on 2015 is Maternal Mortality Rate (MMR) is 305 per 100,000 live births in Indonesia. The rebozo technique is a non-pharmacological method that makes the muscles of the pelvis more relaxed and gives the pelvic space more space and open so that it helps accelerate the opening of the cervix and help descending of the fetal head, so that can help shorten the time of delivery. The aim of the study was determined the differences in the effectiveness of the rebozo technique on cervical dilatation and descend of the fetal head in active phase of first stage in labor mothers. Methodology of this study was Quasy experimental design. It take pre-post test on one group design. Population and sample were 20 primigravidas mothers in active phase of the first stage of labor. Sampling technique used accidental sampling. The result of this study that there was effectiveness of rebozo technique on opening of the cervix during the active phase with p-value 0.012 . Conclusion is there was an effectiveness of the rebozo technique for descending of fetal head in the active phase of the first stage of maternal delivery with $p$-value 0.028 .
\end{abstract}

Keywords : First Stage; Cervix Dilatation; Descent Of Fetal Head; Rebozo Technique 


\section{PENDAHULUAN}

Persalinan merupakan rangkaian proses yang berakhir dengan pengeluaran hasil konsepsi dari intrauteri ke ekstrauteri oleh ibu. Tahapan awal dari persalinan adalah kalah I yaitu adanya pembukaan dan dilatasi serviks, yang terdiri dari fase laten dan fase aktif. Fase laten adalah mulai adanya kontraksi yang teratur dan diikuti dilatasi serviks sampai dengan $3 \mathrm{~cm}$ sedangkan fase aktif adalah interval stelah fase laten yang diikuti dilatasi serviks sehingga lengkap $(10 \mathrm{~cm})$. (Dini Kurniawati,2017; Varney, 2008)

World Health Organization (WHO) menyatakan bahwa kematian seorang ibu adalah kematian seorang perempuan waktu hamil atau dalam 40 hari setelah berakhirnya kehamilan oleh sebab apapun, terlepas dari tuanya kehamilan dan tindakan yang dilakukan untuk mengakhiri kehamilan. Menurut laporan WHO (2013), kematian ibu di dunia disebabkan preeklampsia 28\%, perdarahan 27\%, eklampsi $14 \%$, aborsi tidak aman $8 \%$, infeksi $11 \%$, penyulit persalinan $9 \%$ dan emboli 14\%. (Rasdianan, 2016)

Berdasarkan data hasil Survei Penduduk Antar Sensus (SUPAS) tahun 2015, tercatat Angka Kematian Ibu (AKI) sebesar 305 per 100.000 kelahiran hidup, sedangkan menurut data hasil Survei Demografi Kesehatan Indonesia (SDKI) tahun 2012 tercatat AKI sebesar 359 per 100.000 kelahiran hidup. Penyebab kematian ibu di Indonesia adalah infeksi
$(55,6 \%)$, dan lain-lain $(34,5 \%)$, perdarahan $(30,1 \%)$, hipertensi dalam kehamilan $(26,9 \%)$, partus lama $(1,8 \%)$, abortus (1,6\%). (Rasdianan, 2016; Depkes RI, 2015)

Dalam proses persalinan bila terjadi kelemahan dalam kontraksi uterus akan terjadi pembukaan serviks yang memanjang. Fase pembukaan serviks yang memanjang dapat disebabkan oleh kelemahan otot uterus dalam berkontraksi. Selain itu pembukaan serviks memanjang dapat juga disebabkan oleh kekuatan mengejan yang dimiliki oleh ibu, faktor janin, faktor jalan lahir, faktor psikis ibu yang terdiri dari tingkat kecemasan dan rasa takut yang dialami dalam menghadapi persalinan. Dan jika terjadi pembukaan serviks yang memanjang akan menyebabkan perpanjangan waktu kala I yang disebut dengan kala I memanjang. (Surtiningsih, 2017; Sadiyah,2014).

Berdasarkan data Angka Kematian Ibu (AKI) di Provinsi Jawa Tengah tahun 2017 tercatat sebanyak 88,58 per 100.000 kelahiran hidup (475 kasus) mengalami penurunan dibandingkan dengan tahun 2016 yaitu 109,62 per 100.000 kelahiran hidup (602). Penyebab kematian ibu adalah perdarahan (19,09\%), hipertensi dalam kehamilan (32,97\%), lan-lain $(30,37 \%)$ gangguan sistem peredaran darah $(12,36 \%)$, gangguan metabolisme $(0,87 \%)$ infeksi $(4,34) \%$. (Dinkes Provinsi Jawa tengah, 2017)

Salah satu upaya untuk menangani kala I memanjang saat proses persalinan 
dapat dilakukan dengan metode farmakologis dan nonfarmakologis. Salah satu metode nonfarmakologis yaitu dengan menggunakan teknik Rebozo. Rebozo membantu memberikan ruang pelvis yang lebih luas untuk ibu sehingga bayi lebih mudah menuruni panggul dan proses persalinan menjadi lebih cepat. (Jaskara, 2020; theasianparent.com)

Tujuan penelitian ini adalah untuk mengetahui efektifitas teknik rebozo terhadap pembukaan serviks dan penurunan kepala janin ibu bersalin kala I pada fase aktif.

\section{METODOLOGI PENELITIAN}

Penelitian ini merupakan penelitian kuantitatif dengan desain menggunakan jenis penelitian eksperimen semu (quasi experimental design). Penelitian ini dilakukan pada bulan Juni 2019, di Praktek Mandiri Bidan (PMB) C di Kota Semarang. Sampel yang diambil dalam penelitian ini adalah 20 responden, yang dikelompokkan menjadi 2 kelompok yaitu kelompok intervensi yang mendapatkan perlakuan dengan teknik rebozo dan kelompok kontrol yang diberikan melakukan pelvic rocking yang sesuai kriteria inklusi. Uji normalitas data menggunakan uji ShapiroWilk, sedangkan untuk menguji efektiftas teknik rebozo pada kelompok intervensi dan kontrol terhadap pembukaan serviks dan penurunan kepala janin pada ibu bersalin kala I fase aktif menggunakan uji Mann-Whitney.
HASIL PENELITIAN DAN BAHASAN

Di bawah ini merupakan analisis Statistik Perbedaan Efektivitas Pembukaan Serviks Ibu Bersalin Pada Kelompok Intervensi (Teknik Rebozo) dan Kelompok Kontrol

Tabel 1. Analisis Statistik Perbedaan Efektivitas Pembukaan Serviks lbu Bersalin Pada Kelompok Intervensi (Teknik Rebozo) dan Kelompok Kontrol

\begin{tabular}{cccc}
\hline Kelompok & $\mathbf{N}$ & Mean & $\boldsymbol{\rho}$ value \\
\hline Intervensi & 10 & 3.80 & \\
\hline Kontrol & 10 & 3,30 & 0,028 \\
\hline
\end{tabular}

Berdasarkan tabel 1 dapat diketahui nilai median atau nilai tengah setelah dilakukan teknik rebozo sebesar 10,00 dan kontrol sebesar 9,00. Uji Statistik menggunakan Mann-Whitney Test diperoleh $\rho$ value untuk selisih antara kelompok intervensi teknik rebozo dan kontrol sebesar 0,018 0,05 maka $\mathrm{Ha}$ diterima, sehingga disimpulkan bahwa ada perbedaan efektivitas intervensi dan kontrol terhadap pembukaan serviks ibu bersalin kala I fase aktif di PMB C Kota Semarang.

Nilai mean rank intervensi teknik rebozo 13,30 lebih besar dari nilai kontrol yaitu 7,70 yang berarti bahwa teknik rebozo lebih efektif terhadap pembukaan serviks ibu bersalin kala I fase aktif.

Di bawah ini merupakan analisis statistik penurunan kepala janin pada Kelompok Intervensi (Teknik Rebozo) dan Kelompok Kontrol 
Tabel 2. Analisis statistik penurunan kepala janin pada Kelompok Intervensi (Teknik Rebozo) dan Kelompok Kontrol

\begin{tabular}{ccccc}
\hline Kelompok & $\mathbf{N}$ & Median & $\begin{array}{c}\text { Mean } \\
\text { Rank }\end{array}$ & p value \\
\hline Intervensi & 10 & 10.00 & 13,30 & \\
\hline Kontrol & 10 & 9,00 & 7.70 & 0,018 \\
\hline
\end{tabular}

Berdasarkan tabel 2 dapat

diketahui nilai rata-rata setelah dilakukan teknik rebozo sebesar 3,80 dan kontrol sebesar 3,30. Uji Statistik menggunakan Mann-Whitney diperoleh $\rho$ value untuk selisih antara kelompok intervensi (teknik rebozo) dan kontrol sebesar 0,028 $<0,05$ maka Ha diterima, sehingga disimpulkan bahwa ada perbedaan efektivitas kelompok intervensi dan kontrol terhadap penurunan kepala janin pada proses persalinan di Praktik Mandiri Bidan C Kota Semarang.

Teknik rebozo adalah terapi non farmakologi untuk mempercepat pembukaan serviks ibu bersalin. Dalam penelitian membuktikan keefektifan teknik rebozo untuk pembukaan serviks sehingga mempercepat kemajuan persalinan. Peneliti melakukan penelitian dengan metode pra eksperimental yang menyimpulkan bahwa terdapat perbedaan atau selisih pembukaan serviks ibu bersalin sebelum dan setelah dilakukan teknik rebozo di bandingkan dengan kelompok kontrol pada penelitian ini kelompok kontrol dilakukan pelvic rocking. Hasil penelitian Wulandary dkk yang menyimpulkan bahwa ibu bersalin kala I yang melakukan pelvic rocking exercise dapat mempercepat kemajuan persalinan di Rumah Sakit Umum Daerah (RSUD) Ungaran (Wulandari, Wahyuni, 2019). Teknik rebozo dan pelvic rocking merupakan metode non farmakologi yang menjadi alternatif praktis dalam menangani lama penurunan kepala janin dan pembukaan serviks dalam proses persalinan yang bertujuan melenturkan, merileksasikan otot-otot dasar panggul agar kepala janin dapat masuk dan turun ke jalan lahir.

\section{KESIMPULAN}

Simpulan penelitian adalah terdapat efektivitas pemberian teknik rebozo terhadap pembukaan serviks dan penurunan kepala janin pada ibu bersalin kala I fase aktif. dan teknik rebozo sangat bermanfaat terhadap kemajuan persalinan

\section{DAFTAR PUSTAKA}

1. Dini Kurniawati. Manajemen Intervensi Fase Laten ke Fase Aktif Pada Kemajuan Persalinan. Nurscope: Jurnal Keperawatan dan Pemikiran IImiah. 2017; 3 (4). 27-34.

2. Varney Helen. Buku Ajar Asuhan Kebidanan, Ed. 4. Vol. 2. Jakarta: Penerbit Buku Kedokteran EGC, 2008; h. $672-1229$

3. Muhammad Rasdianan, dkk. Karakteristik ibu Yang Mengalami Persalinan Deangan Sectio Caesarea Di Rumah Sakit Umum Daerah Moewardi Surakarta. Naska Publikasi: Universitas muhammadiyah Surakarta. 2016; 1-15.

4. Departemen Kesehatan Repoblik Indonesia. Profil Kesehatan Indonesia Tahun 2015. [Dinkes tanggal 6 September 2017, pukul: 21.00 WIB]. $\mathrm{Di}$ unduh dari 
http://www.depkes.go.id//resources/do wnload/pusdatin/profil-kesehatanIndonesia/profil-kesehatan-indonesia2015.pdf

5. Surtiningsih. Faktor-Faktor yang Mempengaruhi Lama Waktu Persalinan Di Puskesmas Klampok 1 Kabupaten Banjarnegara. Bidan Prada: Jurnal Ilmiah Kebidanan. Desember 2017; 8 (2) 101-115.

6. Nailis Sadiyah, Soenarnatalina Melaniani. Pengaruh Faktor Reproduksi Ibu dan Anemia Terhadap Lama Persalinan Kala I Fase Aktif. Jurnal Biometrika dan Kependudukan. Desember 2014; 3 (2) 136-142.

7. Dinas Kesehatan Provinsi Jawa Tengah. Profil Kesehatan Provinsi Jawa Tengah Tahun 2016 [Diakses tanggal 7 September 2017, pukul: 15.30 WIB] Di dapat http://www.dinkesjatengprov.go.id/v20 15/dokumen/bukusakuth2016/mobile/i ndex.htm\#p=20.

8. Dela Jaskara. Healthy Pregnancy, Gentle Birth and Mindful Parenting; 2015. Child birth International.

9. Febby. Rebozo Technique: Membantu Persalinan Lebih Nyaman dengan Jarik. The Asian Parent Indonesia

10. Wulandari Lany $C$ dan Wahyuni Sri. Efektifitas pelvic rocking exercise pada ibu bersalin kala I terhadap kemajuan persalinan. EF press digmedia: 2019. Gajah Mungkur, Semarang 